\title{
Några ord om Heinrich von Kleist
}

\section{Av Evald Johansson, docent i tyska}

\author{
Länk till presentation av Evald Johansson
}

Nej, han var väl inte så särskilt intresserad av att möta andra människor. Han kände sig för det mesta som en misslyckad figur, ensam och utanför. Han var en gåta för sig själv - en stort anlagd karaktär, som frättes sönder inifrån av tvivel på den egna förmågan och av självanklagelser. En enda förtrogen vän att luta sig mot hade han under sitt liv, sin halvsyster Ulrike. 34 år och en månad orkade han med eländet. Sedan satte han punkt och gjorde det på ett dramatiskt sätt, fullt värdigt en upphovsman till några av den tyska litteraturens starkaste dramer. Ekot av skotten hörs än. Nyckeln till sitt livs tragedi tog han med sig i graven. Den lär ingen hitta. Han var en gåta för sig själv och förblir en gåta för oss. Hans liv var som ett drama, som snabbt går mot sin peripeti; hans verk en serie absoluta mästerstycken, tillhörande det bästa som frambringats på det tyska språket.

Heinrich von Kleist framstår i dag som en av den tyska litteraturens allra största. Han kan utan vidare ställas vid sidan av Goethe och Schiller. Han hade ambitionen att överträffa Goethe, men när han skrivit något verk färdigt, var hans självkritik obarmhärtig, och ibland förstörde han den färdiga produkten helt och hållet.

Denna korta artikel kan tyvärr bara ge en ofullständig och ytlig bild av Kleist och hans verk. Ändå är jag glad att i denna tidning för småländska läsare få lyfta fram en tysk författare i en tid, då medierna i Sverige är så enögt anglosaxiska och så snävt inriktade på vår egen tid. Som om vi inte hade något att lära av dem som gått före oss!

Heinrich von Kleist föddes i Frankfurt an der Oder år 1777 in i en familj och en släkt som var en av den preussiska statens största officerssläkter. Fadern var kapten och kompanichef. Detta innebar, att Heinrich inte hade något val. Han skulle bli officer. Redan före 15 års ålder var han korpral i Postdams garderegemente och deltog i det så kallade Rhenfälttåget i kriget mot Frankrike. Efter några år tröttnade den hypersensible ynglingen dock på marscherandet och exercerandet och tog avsked. Därefter började ett kringflackande liv runt i Europa. Kleist bodde under längre eller kortare perioder i Frankrike, Schweiz, Italien, Österrike, Tjeckoslovakien och på många olika platser i Tyskland. 1804 gick han åter in i preussisk statstjänst och var verksam i Königsberg, men redan 1806 gav han upp sin ämbetsmannabana för gott. Han stod helt enkelt inte ut med att dag efter dag vända papper ett bestämt antal timmar. Sina sista år kom Kleist att tillbringa i Berlin under ständig kamp för sin existens. Han startade en tidskrift, Berliner Abendblätter, av eftervärlden mycket beaktad, men den levde blott ett halvår. Han brevväxlade med Preussens ledande minister, friherre von Hardenberg, för att få en statspension, dock utan framgång. Allt detta bidrog till att fördjupa den depression, som nästan alltid tyngde honom. Tankar på självmord, som han haft många gånger tidigare, dyker upp igen. Och nu gör han allvar av dem. Men han var uppenbarligen rädd för att ensam möta döden. Först frågade han sin kusin Marie von Kleist, just då olycklig på grund av en förestående skilsmässa, om hon ville gå i döden med honom. Hon hade inte mod till det. Kleist fick en tids respit, som dock inte blev lång.

Genom en av sina bekanta hade han lärt känna Henriette Vogel, hustru till en officer i den preussiska armén. De musicerade tillsammans i det Vogelska hemmet. Detta möte mellan två människor i musiken var för båda en lisa, ett reningsbad, en tröst. Det gav dem ögonblick av glömska. Han kunde glömma sina bekymmer och hon sin sjukdom. Hon led nämligen av en obotlig sjukdom - som tycks ha varit livmodercancer - och hon visste, att 
hon snart skulle lämna denna världen. Läkaren hade sagt det. Musikstunderna blev för båda, men kanske framför allt för Henriette, stora glädjestunder, men glädjen var inte oblandad. I bakgrunden malde sorgen. Vid ett tillfälle tog Kleist upp tanken på att förenas i döden. Henriette reagerade nästan direkt. För henne var livslusten flyktad. Så förberedde de sig var och en på sitt håll. Kleist skrev två avskedsbrev till Marie von Kleist och ett till älsklingssystern Ulrike. I brevet till Ulrike står de satser, som så ofta citeras: "Du har gjort allt, jag säger inte vad en syster utan vad en människa förmår för att rädda mig. Sanningen är: För mig fanns ingen hjälp att få i världen."

Den 20 november 1811 åkte de till ett värdshus vid Wannsee utanför Berlin. De åt, som det berättas, förnöjda tillsammans, drack kaffe och gick sedan till vila. Nästa dag betalade de sin nota hos värden, tingade ett bud för sina brev till Berlin, åt och drack kaffe och gick sedan ungefär 50 steg bort utmed stranden till sjön. I värdshuset hördes två skott. Kleist hade skjutit Henriette i hjärtat och sedan sig själv genom munnen. Båda torde ha dött omedelbart. Kleist var 34 år, Henriette 31. En stor tragedi, ja, men sådana följder kan ett möte mellan människor också få.

Vad skrev han då? Tyvärr finns inte utrymme för en ingående analys av hans verk. Bara i korthet vill jag säga: Han fullbordade sju dramer, alla genomströmmade av högspänning. Det mest kända och mest spelade världen över är den tragiska komedin Der zerbrochene Krug (Den sönderspruckna krukan).

Dessutom skrev han ett tiotal noveller, alla strängt komponerade och utmärkta av dramatisk täthet och av ett alldeles unikt språk. Den mest kända är Michael Kohlhaas, historien om den lilla människans ofta hopplösa kamp mot myndigheterna. En del annat flöt också ur hans penna, men det får vi lämna därhän. Gå till biblioteket och låna en bok om Kleist! Börja sedan också läsa hans verk! Det blir en omtumlande upplevelse. 